Information for citation:

Musayelyan L.A. Reformy 90-kh i ikh ekonomicheskie i politiko-pravovye posledstviya [The Reforms of the 90's and their Economic, Political and Legal Impacts]. Vestnik Permskogo Universiteta. Juridicheskie Nauki Perm University Herald. Juridical Sciences. 2018. Issue 39. Pp. 36-52. (In Russ.). DOI: 10.17072/1995-4190-201839-36-52.

UDC 1:316:34

DOI: 10.17072/1995-4190-2018-39-36-52

\title{
THE REFORMS OF THE 90'S AND THEIR ECONOMIC, POLITICAL AND LEGAL IMPACTS
}

\author{
L. A. Musayelyan \\ Perm State University \\ 15, Bukireva st., Perm, 614990, Russia \\ ORCID: 0000-0003-0134-5871
}

ResearcherID: 4762-2017

E-mail: lmusaelyan@yandex.ru

Introduction: the paper demonstrates the impact of the 1990s reforms on the current state of the Russian economy and political and legal system of the country. Purpose: to analyze the real causes and the logic of the reformers' activities, to identify the triggers for the emergence and accumulation of crucial problems of modern Russia. Methods: the methodological framework of the research is based on philosophy of materialism, dialectics (development, universal communication, determinism, contradiction), general scientific methods of analysis and synthesis. Results: the negative implications of the reforms were predetermined by the nature and specific method of their implementation, dictated by economic and political interests of the reformers and their handlers. The negative implications of the reforms took the form of economic decline and inefficiency of political and legal institutions. Moreover, the reforms intensified the alienation in different areas of society: alienation of property from the owner, alienation of power from the people, alienation of law from executors. The reforms and method of their implementation were a manifestation of legal nihilism, which sometimes was covert, sometimes not. As a result, Russian society acquired a parasitic form of oligarchic capitalism as the basis and essentially one-party political system, based on the authority of the leader, as the superstructure. This organization of society dramatically increases the importance of subjective factors in public life, risk of political destabilization and danger of collapse of the state. Conclusions: the reforms threw Russia back to the category of semi-periphery countries. For an adequate response to modern challenges, our society needs to get a self-sufficient high-technology economy, settled and fullfledged political and legal system, mutual trust between the government and the people as a condition of consolidation. It requires an ideology different from that of the reformers' followers.

Keywords: reforms; neoliberalism; privatization; negative implications; crisis; alienation; political and legal system; legal nihilism 


\title{
Information in Russian
}

\section{РЕФОРМЫ 90-Х И ИХ ЭКОНОМИЧЕСКИЕ И ПОЛИТИКО-ПРАВОВЫЕ ПОСЛЕДСТВИЯ}

\section{Л. А. Мусаелян}

Доктор философских наук, профессор кафедры философии

Пермский государственный национальный исследовательский университет

614990, Россия, г. Пермь, ул. Букирева, 15

ORCID: 0000-0003-0134-5871

ResearcherID: 4762-2017

E-mail: lmusaelyan@yandex.ru

\begin{abstract}
Введение: в статье исследуется влияние реформ 90-х на состояние экономики и политикоправовой системы современной России. Цели: проанализировать подлинные мотивы и логику деятельности реформаторов и выявить факторы, обусловливающие возникновение и накопление современных жизненно важных проблем России. Методологической основой работы являются принципь материалистической философии, диалектики (развития, всеобщей связи, противоречивости, детерминизма), общенаучные методы анализа и синтеза. Результаты: негативные последствия реформ - перманентные экономические кризисы и неэффективные политико-правовые институты управления были предопределены характером и способом осуществления реформ, которые диктовались экономическими и политическими интересами реформаторов и их зарубежных кураторов. Реформы вызвали алиенацию в экономической и политико-правовой сферах общества. В экономике произошло отчуждение собственности от собственника, в политике народа от власти и власти от народа, в праве - правоприменителей от права. Реформы, как они осуществлялись, были вуалированным, а в ряде случаев демонстративным проявлением правового нигилизма. В итоге Россия в базисе приобрела паразитарную форму олигархического капитализма, мотивированного на вывоз капитала, а в надстройке при формальном существовании многопартийности возникла однопартийная политическая система, фундированная на авторитете лидера. При такой конструкиии резко возрастает значение субъективного случайного фактора в общественной жизни, усиливаются риски политической дестабилизации и распада государства. Выводы: реформы отбросили страну на полупериферию мир-истории. Для адекватного ответа на современные вызовы, с которыми сталкивается Россия, необходима самодостаточная высокотехнологичная экономика, устойчивая, эффективно функиионирующая политико-правовая система, взаимное доверие власти и народа как условие консолидации общества. Для этого нужна иная идеология, чем та, которой придерживаются современные единомылленники реформаторов во властных структурах.
\end{abstract}

Ключевые слова: реформы; неолиберализм; приватизация; негативные последствия; кризис; отчуждение; политико-правовая система; правовой нигилизм

\section{Introduction}

Though important in the life of modern society, political legal institutions are not selfsustainable. As one of German lawyers put it, their existence and development "are rooted in material relations of life", which the scientist called the basis of the state and law $[25$, p. 6]. However, these relations (the superstructure) not only depend on the economy but are relatively autonomous, and moreover, actively influence their own basis. The superstructure can help develop economy and other spheres of social life, but it can also turn into a destructive factor that worsens the crisis phenomena in the basis, and finally the superstructure itself [ 43 , 44]. For a long period of time, the mutual influence of economy and political legal institutions has been the subject of research for scientists, including lawyers, both in our country and abroad [40].

\section{The Reforms of the 90s and Factors of Their Negative Effect}

Experts characterize the current state of economy and law in our country as crisis [14, 37]. To a great extent, this crisis is the consequence of the reforms introduced in the 90s. The impact of those goes far beyond their specific historical negative consequences, because they drastically changed the vector of Russia's historical route, the typology of the political legal institutions, their social basement, subjectivity, principles of managing all the spheres of the social life. As a result of the reforms, the country became opened to the world and gradually integrated into the global economic, financial, information, educational and legal framework. At the same time, due to the reforms Russia faced a threatening growth of its financial, technological, grocery, medicinal dependence on the world market. Economic crises that 
periodically take place in different regions of the capitalist world devastatingly reverberate in Russia. Of course, in the conditions of openness to the world, the influence of the global market instability onto the national economy of any state is inevitable. However, if we consider the fact that the two last global crises of 1998-1999 and 2008-2009 did not have such consequences in the PRC, the FRG, Sweden and other countries integrated into the global economy, as they did in Russia, it is hard to escape a conclusion that the reasons of the repetitious recessions in our country should be sought in the institutions governing the country. For many years, Russia has been practicing manual control, that is when the President is the main actor of effective solving the economic, social, political legal problems even in the province. And this fact is indicative of a critically low efficiency of the political legal institutions. However, democracy is the government of laws but not a person [10, p. 14]. If we call things as they are, one can speak about the crisis of the country's political legal institutions.

A significant factor that negatively influences the economic situation and ultimately the country's political legal institutions is such a component of the superstructure as the ideology of the Russian elite. Both domestic and foreign researchers have been writing a lot about the characteristics of the post-Soviet elite that were formed in the $90 \mathrm{~s}$. Here, it is worth mentioning the point of view of two distinguished American scientists, Nobel Prize winners in economics, M. Castells and J. Stiglitz. Both had a good knowledge of the ideology and the technology of the reforms introduced in Russia, and of the professional qualifications of the reformers. "Economy collapsed by reason of the speculative manoeuvres of the privileged class for their own benefit and the irresponsible recommendations from the International Monetary Fund, from some of the western advisers and politically inexperienced economists, to implement abstract policy of the free market. All that resulted in unbearable sufferings of the people. The criminal economy has gained the proportions unprecedented for a large industrial country, having connected itself to the world's criminal economy and becoming a fundamental factor that cannot be disregarded both in Russia and internationally" [15, p. 490].

In J. Stiglitz's opinion, the ideology of neoliberalism with its macroeconomic strategy of the "Washington Consensus" introduced in Russia in the 90 s, led to economic decline, massive impover- ishment of the population, critical social stratification of the society. In 1989 , only $2 \%$ of the Russians lived in poverty, while in 1998 there were $23.8 \%$ of them (with the criteria of 2 dollars per day). If the criteria is taken as 4 dollars a day and less, the poor comprised more than $40 \%$ of the population [35 p. 187]. "Russia, as the American scientist concludes, has gained the worst of the possible statuses of the society, the colossal decline accompanied by the same growth of inequality" [35, p. 188]. And this, as J. Stiglitz notes, happened in every country where the USA managed to impose the market fundamentalism ideology. The countries that turned a deaf ear to advisers from the IMF and Wall Street, had quite a different situation, as the scientist shows. In view of this, J. Stiglitz compares modernization in China and reforms in Russia. In China, the modernization program was developed with the use of its own resources. Consequently, "in 1990 the GDP of China was estimated at $60 \%$ of the Russian one, but by the end of the 20 th century, the proportion became the opposite. At the time when Russia suffered unprecedented poverty growth, China experienced unprecedented poverty reduction" (per $150 \mathrm{mln}$ people. - L. M.) $[35$, p. 24]. In accordance with the competent opinion of the American economist, such quite different consequences of the reforms in China and Russia are explainable, as "the liberalism program was not a program of growth, it allowed for the degradation, the theft of the assets and the outflow of capital" $[35$, p. 176].

The negative consequences of the implemented ideology were worsened by the subjective traits of the Russian reformers themselves. As J. Stiglitz notes, the USA made a bid for the leaders in Russia who appeared to be either incompetent or corrupted or both [35, p. 224].

At the beginning of the noughties, the new President of Russia publicly distanced himself from the reformers of the $90 \mathrm{~s}$, who adhered to the market fundamentalism. However, the government of the country that consisted mostly of the liberals continued to practice exclusively monetarist methods of economic management. Consequently, Russia could hardly get out of one crisis when it got wrapped with another. If we continue to compare the economic development of Russia and China over the last 16 years, we will get the evidence of even greater lagging of our country. For example, at the end of the 90s the Chinese GDP exceeded the Russian one by $40 \%$, but in 2015 this indicator of the Celestial Empire's economy was almost 9 times 
as large as the one of its northern neighbor. In absolute figures, these values were 10.8 trillion US dollars - number two in the world, and 1.23 trillion US dollars - number 12 in the world [49]. 1990 through 2014, Russian export of the hightechnology product (HTP) grew 4.5 times in volume (and reached 9.8 billion of US dollars) and the Chinese one - 130 times (and reached 558.6 billion of US dollars). According to estimates of the World Bank, the PRC share in the world's HTP product was $26 \%$ versus the US $7.2 \%$ share. Russia's share has not changed and is less than half a percentage $(0.46 \%)$. In other words, the HTP supply to the world's market by China is 57 times greater than by Russia [52]. China's success is the result of active investment policy. In 2015, the bank credits reached 18.8 trillion US dollars (170\% of GDP) with the Central Bank key rate of $2.25 \%$ and the average commercial banks key rate of $4.4 \%$ [61]. In contrast, the key rate of the central Bank of the Russian Federation was $17 \%$ at the beginning of 2015 , and $11 \%$ at the end of 2015 [34]. The sanctions on the one hand and the credit policy on the other hand suppressed the economy of Russia. It is also important to note that for more than thirty years of reforms, and even in the periods of the world crisis (1997-1998, 2008-2009), China demonstrated stably high economic growth rate, and the same cannot be said of Russia. The comparison of the results of reforms in Russia and China gives reasons for a firm conclusion about the heuristic potential of the neoliberal ideology and the quality of the governing system adopted in our country.

As many researchers note, it is not a coincidence that Deng Xiaoping, the author of the Chinese reforms, was against reforming the country based on the ideology of liberalism [45, 47, 50].

\section{Some of the Reasons for Legal Nihilism in Russia}

The reforms of the $90 \mathrm{~s}$ did not only facilitate the formation of the specific social and economic reality, they also had a significant impact on the public conscience in general, and the public legal conscience in particular. The reformers, having the motivation of a quick destruction of the socialist basis, turned the proposed privatization of property to quick selling the property at low price to persons having close relations with authorities. One can say that the alienation of property from the owner to corporative government structures was the essence of the country transfer from the "Soviet totalitarianism" to "free democratic Russia". And this became a significant factor for the legal alienation distribution in Russia. Alienation in the sphere of law was manifested, first of all, in the relations of the authorities and the masses. And here we will again make reference to the testimony of J. Stiglitz. "A part of the Russian market reformers (and their Western masterminds and advisers) hardly believed in democracy and were hardly interested in it, fearing that if the Russian nation is entrusted to choose, it can make the "wrong" choice, in other words - it can choose a model which is not theirs." [35, p. 168]. Demonstrative disregard of the opinion and the interests of the people, making laws without involving the people into the process meant the alienation of the authorities from the people, the subject of law from the object of it.

The political legal alienation is a two-sided process. If the law making does not respect people's interests, and people themselves are excluded from the law making process, i.e. they do not have "the guaranteed opportunity to realize their potentials-claims in a socially meaningful form, with a result meaningful for the society, then the alienation of the people from both the authorities and the law itself is inevitable" [10, p. 17]. In this case, people are not concerned at all about the state and the law, they do not have any intention to participate in the political processes and influence them. Thus, the social apathy and absenteeism appear which are typical for modern Russia [20].

The alienation of the subject of law from its object on the one hand, and the alienation of the law-maker from the law-making subject on the other hand, is the manifestation of the sharp alienation contradictions, which is a meaningful factor of the massive willful evasion of the citizens from observing the law norms that regulate the individuals' activities in the society. For example, there were 2.166.399 crimes registered in 2014, and 2.352.098 crimes registered in 2015. The expert analysis shows that the real number of crimes is several times greater than the number of the registered crimes [19].

Legal nihilism in Russia is a complicated multi-factored phenomenon conditioned by civilizational and historical aspects of the Russian national development, the population legal culture which seems to be poor when compared with the legal culture of the population in Western countries and so on. However, nowadays, as the analysis shows, the substantive reasons for the high level of crimes in the country are the alienation between the public law administrator and the existing law, and the permanent economic crises that have been recurring since $90 \mathrm{~s}$. The alienation contradiction leads to the legal nihilism not only in the masses but also in the bodies of government of different levels. It is very 
often that people whose status obliges them to develop the laws of the public life and to control their implementation infringe the law themselves. One can spontaneously recall a famous thought by Marx: "A bourgeois treat their regime like a Jew treats the law: he evades the laws as evading is possible in every individual case, but he wants everybody else to follow them" [28, p. 168].

\section{Legal Nihilism and Formation of the Parasitical Oligarchic Capitalism}

The reforms themselves, in the form they were implemented in the 90 s by the new authorities of Russia, were nothing else but the veiled legal nihilism, and in a number of cases - the uncovered manifestation of it. "The privatization performed through the shares-for-loan auctions, as J. Stiglitz notes, was politically illegal. The oligarchs did not have legitimate property rights and so they were fast to export money from Russia" [35, p. 194]. It is obvious that the Russian liberals' point of view about the events of those years is different. However, the assessment of the legal expert community of our country coincides with the point of view of the American scientist. The privatization, as the analysts say, had an illegal nature not only because of the "breach of the current legislation, but first of all because of the illegal character of the legislation itself" $[10$, p. 18]. The illegal character of the legislation resulted in the illegitimate property, and this in turn led to a colossal motivation to export the capital. In short, the illegal privatization (or else legal nihilism) contributed to a parasitic form of using the resources [10, p. 18]. A sizeable portion of the owners and officials in Russia obtained the psychology of temporary place-holders who neither think about the perspectives of their business nor about the future of their country.

This is evidenced by an unacceptably low innovation activity of the Russian companies. For example, if in 2009 only GM on its own invested 9 billion dollars into research and development, then the cumulative investment of all the big Russian companies for this purpose mounted up to 800 million dollars [31]. As the researchers note, neither the state nor the business has an internal interest for innovations and modernizations. In 2013, Russia's position in the world's innovation index rating was 64 out of 132 positions [18, p. 9]. A new economic crisis that started in 2014 and the sanctions of the West understandably did not contribute to the improvement of the situation with the innovative activities. In 2016 the investments into research and development in the USA amounted to 456.9 billion dollars, in PRC - 336.5 billion dollars, while in
Russia they amounted to 40.7 billion dollars [60]. With the incomparable expenditures on research and development, the efficiency of the Russian innovation fund was 112 times lower than that of the American one [31]. The low efficiency of the innovation and modernization programs was to a great extent conditioned by the soaring corruption [7, 38]. By exporting money from the country, the Russian business followed the example of its government, where, as previously noted, the key positions were held by neoliberals. As ex-minister of finance A. Kudrin announced publicly, in 20002008 the state made 1 trillion dollars from exporting hydrocarbons, a half of the sum being the unplanned earnings from the oil price growth. "The petro-dollar rain" could allow for the reindustrialization of the whole Russia, and if not for catching up with the technologically advanced countries then at least for significant reducing of the gap. However, the government, strictly following the IMF recommendations, was performing the "sterilization" of the money received, investing it into the USA securities and the European banks. Exporting the money obtained from selling the natural resources of the country, the Russian government together with the oligarchs actually invested economies of the geopolitical enemies of Russia instead of steering their own country from the severe crisis. Even now, when the USA has actually declared economic war against Russia, the latter continues to keep almost 190 billion dollars with its geopolitical enemy [57]. It is true that the roots of this strange form of patriotism go back to the beginning of the $90 \mathrm{~s}$. As a result of this policy implementation, during the last fifteen years not only an innovative competitive economy, which would comply with the Russia's status as a superpower, failed to be developed, but the further degradation of the fundamental sphere of the social life took place [7]. By way of contrast, over the years of reforms, China has turned from a technically backward country into a high volume importer of information technology products $(39 \%$ of the world market) [60].

For the sake of fairness, it is worth noting that lately the country's leaders began to recognize the necessity to correct the policy being followed. The demonstratively hostile anti-Russian policy maintained by the USA and their allies for the last three years, the economic sanctions adopted by them in breach of the international law aiming at making a "technological ghetto" out of Russia like it was in the "cold war" period, seem to sober the Russian political elite. In response to the finance and technological asphyxiation of Russia, the authorities 
declared the policy of import substitution, the counter-sanctions were introduced, the funding of the agricultural and, fragmentarily, of some other sectors of productive economy was increased. However, the problems that have been accumulating for 20-25 years in the country's economy cannot be overcome through adopting the palliative measures. But it is highly questionable whether the people adhering to neoliberal ideology can get Russia out of that track pits leading to the periphery of the world history, where their ideological allies brought it at the beginning of the $90 \mathrm{~s}$.

Furthermore, the question arises about the policy of the business-society. Can the "comprador bourgeoisie" that was formed in the $90 \mathrm{~s}$, change they mentality, commit themselves and their children to Russia? The question is rhetorical. For example, if the GDP of the country was down by $3.7 \%$ at the height of the crisis of 2015 , then the profit of the companies grew 1.5 times as compared to the relatively good 2014 when the oil price was more than 100 dollars per barrel. In specific sectors of economy, the profit grew between 4 and 17 times [41, p. 164]. The experts ascribed the financial prosperity of the companies in the conditions of crisis and production decrease to the uncontrolled driving up the prices for goods and services by enterprises, including the state-owned ones. In spite of the fast growth of the companies' and banks' profit, the fixed capital investments went down by $8.4 \%$ in 2015 [ 41 , p. 164]. The companies used the earned profit for speculative purposes. The profit of the companies resulting from such activities grew 9 times in 2015 [41, p. 164]. In accordance with the tradition of the $90 \mathrm{~s}$, the business community exported their money from the country. As the Auditing Chamber reported, for the period of 2013 through 2015, i. e. from the very beginning to the top of the economic crisis, there were 1.2 trillion roubles illegally exported from the country through simulated export and import deals [12]. The increase of price for goods and services with the acquiescence of the government, and the Central Bank activities on cheapening the rouble for activating exports, contributed to the growth of inflation, reduction of the actual wages and poverty rate increase. Actually, the authorities left the brunt of the crisis to the population. It is highly questionable whether such a policy of the state complies with Article 7 of the Constitution where the Russian Federation is declared a social State.

\section{Reforms and Their Influence onto the Political and Legal Institutions of Our Country}

The reforms of the 90 s caused both alienation in the sphere of law and deformation of the whole system of the political legal relations in the postSoviet Russia [23]. Here two facts are worth noting. The denationalization of the property in the form it was arranged, could not happen with strong state institutions and effective law enforcement authorities. That is why, the aggressive campaign in mass media, aimed at discrediting the state institutions, military forces and law enforcement bodies was the necessary condition for the USSR breakup, and then - for the alienation of property from the owner. The blackening of the political and legal institutions made honest and professionally prepared employees leave these institutions. The humiliating rate of wages added to it. The vacancies were filled with random people, hardly suitable in terms of their professional and moral psychological features. The personnel were not selected but just hired, and so many of the new employees turned to be potential "corrupt cops" - people having direct or indirect relations with the criminal groups. In sum, the reforms of the 90 s led to a significant change in the quality of the personnel engaged with the political legal (and especially legal) institutions of the country. Abusing of official positions, corruption, crimes became a frequent occurrence in the Russian law enforcement institutions. To clear different "corrupt cops" out the police, and to increase the efficiency of its work, the reform of the Ministry of Internal Affairs was put in place in 2009-2011 at the President's initiative that cost the budget 2 billion roubles [32]. However, the events of the recent years give reason to believe that the most significant results of the reforms were expressed mostly in the sphere of semantics [42]. The frequency of the dreadful scandals and arrests of the high-ranking police officers with confiscation of incredible amounts of money and valuables means that the disease, acquired by the law enforcement bodies in the 90s, is chronic and cannot be neutralized with cosmetic procedures.

The law, just like the crime, i. e. the struggle of separate individuals against the dominating relations approved by the state, do not originate from pure lawlessness. They are ultimately defined by the existing basis and the level of the society's culture development conditioned by it [27, p. $19 ; 28$, pp. 322-323]. That is why the legal institution crisis means a system crisis of the whole society, of all the spheres of the public life. A noticeable contribution to changing the quality of the law enforcement bodies (and other bodies) 
was made by the educational reform introduced in the 90 s.

Changes in education and science, as the author of the work sees it, correlated with the purposes of reforms in economy. Such correlation was not accidental, as both the reforms were motivated by the same neo-liberalism ideology. From these positions, educational establishments are the subjects of economic activities, and in the market conditions, they have to strictly follow the principle of "minimum expenses and maximum profit". Adherence to this principle resulted in dehumanization of the education process, to significant reduction of the academic disciplines which are the foundation of the high-quality professional activities. The results of the reforms were quick to influence the level of the Russian education, including the juridical education. By the end of the noughties, the then Head of the Ministry of Education and Science, A. A. Fursenko, noted that only $7-10 \%$ out of the 700 thousand of graduating lawyers had a proper qualification [9].

The reforms of the Russian education were accompanied not just by the dehumanitarization and dehumanization of the education process, but also by elimination of moral, cultural and worldview components from it. The competent opinion of $\mathrm{V}$. Zorkin is that excluding the moral tasks from the education system and turning it into the sphere of providing education services allowed for destroying the general moral normativity and deleting the image of attractive future from the collective consciousness of the post-Soviet countries, and finally created a fertile soil for terrorist recruiters, who showed the young "the true purpose of life" that could not be found in close social realities [11]. The reforms of the 90s radically changed the lifepurpose values, attitudes, the way of thinking and lives of people. Money became the supreme value, the pursuit of money and money accumulation became the purpose of life. Collectivism, selfsacrifice, solidarity were gradually replaced by individualism, egoism, suspicion and aggression in relations between people. One can say that in consequence of the reforms, the civilization code of Russia actually changed.

New modern social reality creates new lifepurpose values, attitudes and work motives of the young Russians. That is why, there are many graduates of the higher educational establishments who get employed in the law enforcement and law application institutions and bodies of government, having motivation which is quite opposite to the motivation of customs officer P. Vereshchagin from famous Soviet film "Beloye Solntse Pustyni" ("The White Sun of Desert"). If the successfulness and importance of the person is defined by the amount of money in his possession, then he obtains a motive to view the public service as a power resource that gives an opportunity to improve his welfare and social importance. Unlawful enrichment in civil service is understood by him as economic rent for working for the state. Unlike the customs officer Vereshchagin, for him it is not "painful to see his country suffering", because everyone enriches themselves as best as they can. It is clear that the higher the employee's status is, the higher the rent is. That is why the career advancement got a clearly expressed economic motivation. Professionalism as a factor of vertical mobility is more and more replaced with protectionism driven by family ties or corporative relations, and even by a practice of "purchasing the positions".

It is obvious that the capitalization of bureaucracy is impossible without uniting the interests of a definite part of the business community and the representatives of the bodies of government. That is why the capitalization of the bureaucracy is accompanied by the bureaucratization of the capital $[10$, p. 18]. This is manifested not only in the increasing impact of the capital on the government but also in the active involvement of the business community representative into administrative institutions [2, 17]. For some reason it is believed that a successful businessman should necessarily be an effective bureaucrat.

Meanwhile, the motives of activities of a businessman and of a "people's servant" are different, if not antipodal. The first one, pursuing his own interests, is busy with improvement of his well-being. The second one is obliged to be guided by the interests of people and provide for the conditions of their good living. The criteria for defining the efficiency of a businessman and of a government official are also different. If a businessman is guided by the principle of minimum expenses and maximum profit, then applying this principle to managing, for example, the public health system or the system of education, as the Russian experience proves, is counter-productive. For a businessman joining the state service, it is difficult to switch over and abandon his usual principles and motives of activity. The high profile criminal cases initiated in recent years against the state officials of different levels prove that a former businessman, having started a career of a city 
manager or the RF constituent territory, continues his usual practice, i. e. earning money. The choice between respecting the law and a quick enrichment is not always made in favor of the law. And if there is big money at stake, as Marx noted, even the awareness of the inevitability of severe punishment cannot deter a bourgeois from committing the crime $[26$, p. 770$]$. Such a choice is to a great extent conditioned by the moral atmosphere in the country, which was discussed above. Capitalization of the bureaucracy and bureaucratization of the capital is one of the reasons for the reduction in professionalism and quality of work of the administration bodies. At the same time, such a union gives competitive advantages to the political elite and its party during the elections. It was noted long ago that getting votes through employers is more effective than buying the votes directly [48].

As discussed, the reforms resulted in the transformation of the basis and this in its turn added to the superstructure change. However, if we go back to the scientific methodology of researching the political legal institutions, the superstructure does not only depend on the basis but also has a relative autonomy and actively influences the basis.

It should be pointed out that the economic reforms were preceded by the dramatic events of September and October of 1993 that ended with shooting the RSFSR Supreme Soviet. As A. Tsipko rightly noted, the dissolution of the Parliament demonstrated "not the conflict inside the nation, but the war between the governing groups. Yeltsin and Gaidar wanted immediate and total reforms including privatization of the oil industry: and the Parliament supported gradual reforms" [3]. But it is more than that though. Shooting the Parliament was a logical continuation of the Belavezha Accords (December 8,1991$)$ that initiated the beginning of the USSR liquidation. This document triggered by the Russian liberal political elite and signed by the leaders of three Soviet republics, declared the disestablishment of the Soviet Union as the object of the international law and geopolitical reality. The agreement was ratified by the Supreme Soviet of Russia but it was three times rejected by the IV Congress of People's Deputies, and this prevented it from being legally binding. The antagonism between the President and his palace guard on one side, and people's deputies on the other side, was settled by Yeltsin by shooting the Parliament from the tank guns. Years later, when the smoke of the tank guns dissipated and the information fog melted away, many facts became known. During the events, 150 people died and about 400 were wounded. It was also found out that a third party secretly participated in the dramatic events in Moscow at the end of September - beginning of October of 1993. It is a well-known fact that the President received the "sanction" to shoot his Parliament from Washington. This explains why the world's "democratic" mass media wrote nothing about the non-democratic actions of the Russian democrats. Besides, during the capture of the Russian Government House, just like it was during the "colored revolutions", there were unknown snipers shooting as well from the roof of the American Embassy. Could the armed men get to the roof of the embassy unnoticed by the Americans? - the question is rhetorical. Both the military men and the defenders of the Parliament were shot [3]. It is obvious that the organizers of the first colored revolution in Russia aimed at kindling a great murderous civil war.

And, finally, there is one more symptomatic fact. Right after signing the Belavezha Accords, B. Yeltsin informed D. Bush about that (to be more exact, reported about that). This means that the new political elite of Russia coordinated its activities on dismantling the existing political system (and then the basis of it) with its oversea supervisors. However, the modern non-systematic opposition in Russia acts in the same way struggling for power.

Let us, however, go back to the events of the beginning of October in 1993. When evaluating them, A. Tsipko notes: "Russia was the only country of the Western Europe that reached its objective (transited from socialism to capitalism. - L. M.) through blood" [3]. As known, the President flatly refused to apologize to people for the spilled blood. "Since Yeltsin shot the Parliament in 1993, as A. Tsipko points out, a yawning gulf appeared between the people and the government. People adopted an attitude towards the government as if they had nothing in common with it" [3]. That makes sense because the attitude of the government to the people was demonstratively disinterested, and that was manifested not only in 1991 and 1993, but during the presidential elections of 1996, when B. Yeltsin won re-elections through the vote rigging.

\section{Features of the Political System of Modern Russia}

The events of the beginning of the 90s show that the first actions of the new Russian political elite that were historically important for the 
country's future went far beyond the legal framework and public political consensus. This resulted in the mutual alienation of the people and the government, which, in turn, determined the special features of the Fundamental Law of the country and the forming political system.

The existing mutual alienation between the ruling liberal elite and the people gave no reason to believe that the President's supporters would dominate the new parliament. The Fundamental Law was developed by the ideological and political supporters of Yeltsin. Hence, it follows that the presidential powers were in fact unlimited and the parliament was almost powerless. To stand against opposition, B. Yeltsin and his supporters needed a powerful political and legal instrument and they got it. It is obvious that the political and legal asymmetry in the authorities has little to do with democracy, but it ensured the safety of B. Yeltsin's power and, one should confess, even added to a relative political stability in the country. H. Hale called the created political construction "presidential". It makes it easy for the "patron" to retain power and to coordinate the interests of different elite groups within the framework of the authoritarian constitution. The consequences of the "patronalism" are corruption, small social capital, disrespect for law, nepotism [51]. One has to agree with the conclusions of the American researcher.

Seemingly, the principle of the human rights priority was introduced into the Fundamental Law under the influence of the foreign advisers. As V. V. Lapaeva notices, this human-centrist principle was not supported with a specific juridical dogmatics having a systematic centrist character [21, p. 148; 22]. The same can be said about declaring Russia a social state. The declarative character of the constitutional norms that affect the interests of the absolute majority of the population reflects the true attitude of the liberal elite and its ideologists to the people. And for many years after the Constitution was introduced, experts have been noticing that "the material, psychological, organizational basis of equality and enforcement of the human rights and freedoms does not correspond to the constitutional provisions" [1, p. 2]. This means that the split of society that occurred in the beginning of the 90s has not been overcome yet. As the famous Russian constitutionalist concludes, "the role of our Constitution in creating the harmony of society has been exceptionally small so far" $[1, p .2]$.
In the conditions of the mutual alienation between the majority of the society and the authorities, the latter were to introduce reforms sensitive for the population, in economy, public health sphere, education, communal services and so on. With no political parties (that belong to the new authorities or people ideologically close to them) in the representative bodies of the country, introducing these reforms would have been impossible. But the traditional method of promoting parties to power did not guarantee success. That is why, during the post-soviet period, the parties were created and propagated "from the top". With this background, as the researchers note, the Russian parties established by the elite and "meant for representing interests of the society in the authorities turned to be authority-formed but not authorityforming structures. They represent the interests of the authorities in the society rather than the interests of the society in the system of the state power" [10, p. 18].

The reforms resulted in the impoverishment of the population, in the growth of protesting electorate and left-wing supporters in the society. This, as the results of the presidential elections demonstrated in 1996, could result in the opposition parties getting a majority in the Parliament. To avoid this situation, different post-modern partiescompanies and parties-phantasms are made up just before the elections, again "from the top", representing predominantly their own interests [4]. The number and activity of such parties significantly increases in the period of elections. The creation of these political simulacra seemingly follows two objectives. The first one is creating the illusion of political competition and real choice for the electorate. But their main objective is to block any opportunity of getting a politically meaningful number of seats in the Parliament by a party that will radically change the internal economic policy of the government in case it comes to power. For completing this task, the "parties-larvae" fragment the electorate base of the political opposition, split it into pieces, disorientate the voters (through the hyperactivity of the parties-clones) etc. As a result of such activity of post-modern parties, of the never-ending amendments to the election law and the legislation about parties (depending on the political situation), of using administrative pressure, the political elite of the country has been able to secure an absolute majority in the State Duma for 
the party of power for many years. This allows the ruling political (and economic) establishment to push any draft law prepared in the President's and Government administration through the Parliament, with no complicated negotiations and approvals.

In relation with the above mentioned, one can make a conclusion that the political system of modern Russia is formally multi-partied, but monopartied in fact. In the conditions of capitalism and current social and economic stratification of the society, a mono-party system is a nonsense. It shows a contradiction between the basis and the superstructure. But this contradiction is external, or formal. The established superstructure is the manifestation of the characteristics of the existing basis that appeared during the reforms of the 90s. "As a result of the "mounted attack" on the public and state property, as A. Frolov notes, the Russian society got oligarchic marginality characterized by a commercial-speculative (as per the classification of M. Weber) or parasitic (as per the classification of M. Musin) form of capitalism, and this marginality had no motivation for real economy and production $[39$, p. 81]. In the author's opinion, the social basis of the political superstructure dominating in the country is the privileged class that exists outside the legal dimension common for the whole Russia. In the business sphere, this class is busy with establishing "pseudo-economic chimeras associated with the manipulation of the capital stocks, securities, stock-exchange speculation and grabbing the property still owned by the state" [39, p. 81].

The public opinion polls show that the Russians predominantly characterize the social order in the country as "oligarchical capitalism", and twothirds of the respondents are sure that the policy pursued by the state does not serve the interests of the majority of the population $[6,13]$.

One of the specific features of the modern political system is the global irresponsibility. Neither the Government nor the State Duma, neither the President nor the deputies are answerable to the voters. The population has practically no channels of influencing the authorities. And this is one of the reasons for low efficiency of the administrative institutions.

The Government does not depend on the voters. The State Duma is not responsible for the activities of the Government because the Government is formed not by the State Duma but by the President. To get the approvals for their decisions, the President and the Government use the support of the United Russia party in the Parliament. But the party's founder who had also been acting as its
Chairman until recently, is not a member of the party. This political "know-how" allowed the supreme representative of the legislative and executive power, depending on the political situation, to distance himself from his "political child" which supports the government policies almost unconditionally.

The deputies of the State Duma are also low dependent on the voters, except perhaps for the elections period, but even then only partially [31]. The transfer from the proportional vote to the mixed one has not significantly changed the situation. The current RF Constitution runs that a voter does not have a right to recall the deputy. The provision covering a recall of a deputy did exist in all the USSR and RSFSR constitutions [33, p. 375]. No dependence of the deputy on the population that elects him, as famous law scientist V. M. Gessen noted, suggests incapability of the people and the negation of the people's sovereignty [5, p. 141]. The lack of trust of the principal law authors in the population reflects the alienated attitude of the Russian political elite to its people acquired at the beginning of the 90s. Maintaining this lack of trust at the present moment is destructive. The problem of relations between the deputy and the voters, as V. P. Reutov noted, was the subject of consideration at the RF Constitutional Court, which indicated in its resolution No. 9-P dated April 12 that the deputies should be guided by the RF Constitution and their own conscience [33, p. 375]. However, in the society where everything can be bought and sold, it has been a long time since conscience became a commodity in short supply and a highly liquid item. Therefore, it is not infrequent that among deputies (of all the levels) there appear people who regard their deputy position exceptionally as a commercial project. No dependence of the deputies on the voters turns to be the factor that negatively influences the quality of the deputy corps. For this very reason, the sociologists register a high level of distrust of the population to the Council of Federation, the State Duma, the political parties $[6,8]$.

In the established political system of Russia, the president of the country holds a special place. This is, first of all, because of his universal authority guaranteed by the RF Constitution; and secondly, because of the personal qualities of V. V. Putin that set him drastically apart from his close predecessors and also from modern politicians. The absolute majority of the Russians positively assess his activities associating them mostly with the external policy of the country. For the majority of the 
citizens of Russia, V. V. Putin is a successful world class politician who sequentially protects the national interest of our country in the international community. It seems that such an understanding of the country leader's role by the people is a national tradition. "The tsar, as H. Kissinger notes, was depicted as the synonym of Russia's struggle against enemies surrounding it" [55]. Besides, for many of the Russians, the President is the last resort in contesting the despotism of the officials and the outrage of the employers. In this activity of his, the President is a protector of the traditional Russian values - the truth and the justice, i. e. the features that people assigned to the Emperor. By reference to the mass media reportable to the government, the President's figure has acquired almost a sacral character in the eyes of many Russians. It is not without the mass media influence that people do not realize that the President is the highest official and the supreme executive power representative. He appoints the Chairman of the Government, key ministers, the head of the Central Bank, his own advisors, and so bears equal with Government responsibility for the pursued neo-liberal policy. High rating of V. V. Putin kept for many years, gives some ground for comparing him with R. Reagan, who was called "teflon" by many American experts, for no scandal could have any impact on his public image. Permanent crises and high-profile criminal cases initiated against governors, highranking officials in the government and the state corporations, not only fail to negatively influence the reputation of the Russian President, but seem to drive the improvement of his rating as an uncompromising corruption fighter.

The postmodern parties created "from the top" differ in the fact that a leader of such party replaces its political program, symbol and brand. The policy becomes personalized. The image of the political party leader becomes a means of the political competition. The failure of the socialists in France at the recent presidential and parliamentary elections was pre-determined by the image of the party and the country, F. Hollande. And vice versa, when the "United Russia" quite unexpectedly for many won the State Duma elections in 2016 at the peak of the economic crisis, it was the result of the high confidence of the voters to the chairman of the party, Russia's President V. V. Putin.

A special feature of the established political system of Russia is in the monocentric and personalistic character of that system. Figuratively speaking, it resembles a pyramid standing on its vertex, or its sharp edge. This vertical system of governance was created at the beginning of the noughties by the president for preventing Russia from disintegration. The President is in the base of the pyramid. For this reason, the political system of Russia, in spite of its multi-party character, is associated (especially abroad) with V. V. Putin (Putin's regime). Let us note that nobody in the whole world would associate the political system of the USA or the FRG with a specific president or chancellor. A normal political system is a stable structure that rests on the wide base of the pyramid. The leaders who are at the top of the pyramid, can change, but the stable political system provides for a balance in the state. Obviously, this is not the case when the pyramid stands on its vertex [53,59].

Monocentric, personalistic, patrimonial character of the political powers is intensified by the meaning of the subjective factor in the country's history. Dozens, and even hundreds of millions of people are trapped by an incidental factor - the personal qualities of the leader. In many experts' opinion, the personalistic character of the governing system was one of the subjective factors of the Soviet Union breakup. "The enormous concentration of power in the hands of one person and the absurd system of the "succession to the throne" did not allow for the stable and trouble-free development, Doctor of Historical Sciences, General Lieutenant of the Russian Foreign Intelligence N. Leonov writes. All one could do was to hope that by chance, a sober-minded, strong-willed politician having a clear plan of development will lead the country" $[24$, p. 20$]$. But is there any guarantee that the strong-willed and skillful V. V. Putin will not be followed by a person with personal qualities like the ones that M. Gorbachev or B. Yeltsin had? The existing system of the political selection of the leaders does not provide for such a guarantee.

The personalistic character of the modern parties contributes to the mediation of the policy. As M. Castells notes, at the moment "the most efficient form of the ideological struggle are attacks against a person. Slander and gossips are becoming the most important skill in politics, as negative messages are five times more effective than the positive ones" [16, p. 64]. It is clear within this framework why the political, ideological, information war initiated across the West against Russia during the last years, is focused on blackening and demonization of Russia's president. Here is the vision of one of Russia's "well-wisher" from the West: "In the West, we cannot stand for 
a long time the consequences of the strongly hostile Putin's statehood - not least because of the fact that the one who will follow Putin might pursue even more nationalistic belligerent policy" $[54,56]$. As A. Rahr, a famous German political analyst, notes, "In the mass media of the West, I see a new demonization of Russia. The Western population is being prepared for a thought of the legitimacy of the intervention against Russia on grounds that "these barbarians" illegally own resources" [58]. Russia, in the opinion of the Western ideologists, is a country of barbarians, because it does not share the European values, it does not respect civil rights, it discriminates homosexuals and ethnic minorities etc. [46]. The anti-Russia campaign at the west is focused, first of all, on V. V. Putin, because his political pyramid is easily destroyable if its base is removed.

It is obvious that such projects do not appear out of nowhere. The patrimonial political system is sensitive to the non-public activities of the foreign actors specialized at "transiting the democracy" to the states with "authoritarian regimes". And the country does have the conditions for preparing the "colored revolution" supported by the internal country's opposition: the lingering economic crisis that decreased the living standards of the population, the stratification of society, being incredible for such a rich country as Russia, pervasive social injustice, corruption, undeveloped democratic institutions and etc. Judging from the public speeches of the president and the ruling party leaders, the political elite understands the risk. Let us see if the adequate actions will be taken that correspond to the challenges.

\section{Conclusions}

The political system adopted in Russia in the noughties, solved specific historical tasks of great importance for the country. It prevented the country from breaking-up, stabilized the social-political situation in the society to a certain degree, and restored the political sovereignty. However, the full sovereignty and independence of the state cannot be achieved without effective actions for overcoming critical economic, financial and especially technological dependence on the geopolitical opponents. If there was not this dependence, the West would not have imposed extensive sanctions on our country, for they would have been purposeless.

The seventeen years that the current political elite have been ruling the country, is enough for re-industrializing the country and developing a high-technology economy. The experience of other countries proves that it is possible. This did not happen because the ruling political elite and the bureaucrats supporting them represent the interests of a small social group whose economic prosperity and world-view were formed as a result of the reforms of the 90s. This small social group is interested in preserving the oligarchical capitalism and the current policy of the Government.

At the moment, Russia is facing new and more risky challenges, and to meet them adequately, other economy is needed, as well as other more efficient managing institutions, other life-purpose values focused on the person but not money.

\section{References}

1. Avak'yan S. Konstitutsiya i Parlament: razmyshleniya po povodu yubileya [Constitution and Parliament: Reflections on the Anniversary]. Rossiyskaya federatsiya segodnya Russian Federation Today. 2008. Issue 23. Pp. 2-3, 16-19. (In Russ.).

2. Balibar E., Wallerstein I. Rasa, natsiya, klass. Dvusmyslennye identichnosti [Race, Nation, Class. Ambiguous Identities]. Moscow, 2004. 288 p. (In Russ.).

3. Baranets V., Gamov A. "Tayny rasstrela "Belogo doma" "[Secrets of the Shooting of the "White House"]. Komsomol'skaya Pravda. 2008. 3 October. Available at: https:// www.perm.kp.ru/daily/24174/385092/ (accessed 12.12.2008). (In Russ.).

4. Galutvina O.K. Partii $i$ vlast' [Parties and Regime]. Svobodnaya mysl' XXI - Free Thought XXI. 2004. Issue 9. Pp. 77-86 (In Russ.).

5. Gessen V. M. Osnovy konstitutsionnogo prava [Basics of Constitutional Law]. Petrograd, 1918. 445 p. (In Russ.).

6. Dobrynina E. Kak po-russki budet schast'e [What' the Russian for Happiness]. Rossiyskaya gazeta - Russian Gazette. 2017. 7 July. (In Russ.).

7. Egorov I. Sygral na instrumentakh [One Played Some Instruments]. Rossiyskaya gazeta Russian Gazette. 2017. 3 March. (In Russ.).

8. Emel'yanenko Vl. Sobstvennaya gordost' [One's Own Pride]. Rossiyskaya gazeta - Russian Gazette. 2017. 29 March. (In Russ.).

9. Zakonnyy brak [Marriage in Law]. Rossiyskaya gazeta - Russian Gazette. 2009. 17 April. (In Russ.).

10. Zelenko B. I. O pravovoy demokratii v RF, vlasti $i$ sotsiume [On Legal Democracy, Regime and Society]. Voprosy filosofii - Problems of Philosophy. 2013. Issue 10. Available at: 
http://vphil.ru/index.php?id=834\&option=com content\&task=view (accessed 30.12.2013). (In Russ.).

11. Zor'kin V. Pravorazrushiteli [Destroyers of Law]. Rossiyskaya gazeta - Russian Gazette. 2017. 27 April. (In Russ.).

12. Zykova T. Po bol'shomu schetu [Generally Speaking]. Rossiyskaya gazeta - Russian Gazette. 2017. 25 January. (In Russ.).

13. Ivanov V. N. Privatizatsiya: itogi i perspektivy [Privatization: Results and Outlook]. Sotsiologicheskie issledovaniya - Sociological Studies. 2007. Issue 6. Pp. 48-60. (In Russ.).

14. Ivanter $V$. Vot novyy razvorot [Here is a New Turn]. Rossiyskaya gazeta - Russian Gazette. 2016. 30 November. (In Russ.).

15. Castells M. Informatsionnaya epokha: ekonomika, obshchestvo i kul'tura [The Information Age: Economy, Society and Culture]. Moscow, 2000. 608 p. (In Russ.).

16. Castells M. Novye individual'nye mass-media [New Individual Mass-Media]. Svobodnaya mysl' XXI - Free Thought XXI. 2006. Issue 5. Pp. 62-67. (In Russ.).

17. Crouch C. Postdemokratiya [Post-Democracy]. Moscow, 2010. 192 p. (In Russ.).

18. Kudrov V. M. Vykhod iz krizisa i innovatsionnaya model' ekonomiki [Economic Recovery and Innovative Model of Economy]. Obshchestvennye nauki i sovremennost' - Social Sciences and Contemporary World. 2013. Issue 4. Pp. 5-15. (In Russ.).

19. Kunina A. N., Rubantsova T. A. Problema preodoleniya pravovogo nigilizma [The Problem of Overcoming Legal Nihilism]. Yuridicheskie nauki: problemy $i$ perspektivy. Materialy IV Mezhdunarodnoy nauchnoy konferentsii Legal science: problems and prospects. Proceedings of IV International Scientific Conference. Kazan, 2016. Pp. 16-17. Available at: https://moluch.ru/conf/law/archive/181/10095/ (accessed 22.07.2016) (In Russ.).

20. Lavrenov S. Ya. Otchuzhdenie kak politikopravovoe yavlenie [Alienation as Political and Legal Phenomenon]. Vestnik Akademii prava $i$ upravleniya - Bulletin of Academy of Law and Management. 2013. Issue 30. Pp. 26-33. (In Russ.).

21. Lapaeva V. V. Postsovetskaya teoriya prava: filosofskie osnovaniya $i$ ikh yuridiko-dogmaticheskaya konkretizatsiya [Post-Soviet Theory of Law: Philosophical Foundations and Their Juridical-Dogmatic Concretization]. Problemy postsovetskoy teorii i filosofii prava: sb. statey - Problems of Post-Soviet Theory and Philosophy of Law. Moscow, 2016. Pp. 146179. (In Russ.).
22. Lapaeva $V . V$. Rossiyskaya filosofiya prava $v$ kontekste zapadnoy filosofsko-pravovoy traditsii [Russian Philosophy of Law in the Context of Western Philosophical and Legal Tradition]. Voprosy filosofii - Problems of Philosophy. 2010. Issue 5. Available at: http://vphil.ru/ index.php?id=136\&option=com_content\&task =view (accessed 01.09.2010). (In Russ.).

23. Lapaeva V. V. Tipy pravoponimaniya: pravovaya teoriya $i$ praktika [Types of Understanding Law: Legal Theory and Practice]. Moscow, 2012. Pp. 315-322. (In Russ.).

24. Leonov N. «Perestroyka»: chetvert' veka spustya [«Perestroika»: a Quarter of a Century Later]. Svobodnaya mysl'XXI - Free Thought XXI. 2016. Issue 3. Pp. 17-34. (In Russ.).

25. Marx K. K kritike politicheskoy ekonomii. Predislovie [A Contribution to the Critique of Political Economy. Preface]. Marx K., Engels F. Sochineniya [Works]. Moscow, 1959. Vol. 13. Pp. 5-9. (In Russ.).

26. Marx K. Kapital. Kritika politicheskoy ekonomii [Capital: Critique of Political Economy.] Marx K., Engels F. Sochineniya [Works]. Moscow, 1960. Vol. 23. 907 p. (In Russ.).

27. Marx K. Kritika Gotskoy programmy [Critique of the Gotha Programme]. Marx K., Engels F. Sochineniya [Works]. Moscow, 1961. Vol. 19. Pp. 9-32. (In Russ.).

28. Marx K., Engels F. Nemetskaya ideologiya [The German Ideology] Marx K., Engels F. Sochineniya [Works]. Moscow, 1934. Vol. 3. Pp. 7-544. (In Russ.).

29. Musaelyan L. A. Istoricheskiy protsess i globalizatsiya [Historical Process and Globalization]. Perm, 2016. 128 p. (In Russ.).

30. Musaelyan L.A. O tsvetnykh revolyutsiyakh, global'nom krizise demokratii i politicheskoy sisteme sovremennoy Rossii [About the Color Revolutions, the Global Crisis of Democracy and Political System of Modern Russia]. Vestnik Permskogo universiteta. Yuridicheskie nau$k i$ - Perm University Herald. Juridical Sciences. 2012. Issue 3 (17). Pp. 33-44. (In Russ.).

31. Primakov E. Stimul k peremenam [Incentive to Changes]. Rossiyskaya gazeta - Russian Gazette. 2010. 8 April. (In Russ.).

32. Proval medvedevskoy reformy MVD. Kto za eto otvetit? [The Failure of Medvedev's Police Reform. Who Will Answer for This?]. Krasnoyarskoe vremya - Krasnoyarsk Time. Available at: http://krasvremya.ru/proval-medvedevskoj-reformy-mvd-kto-za-eto-otvetit/ (accessed 12.03.2017). (In Russ.).

33. Reutov V. P. Naselenie i ego predstaviteli vo vlasti: evolyutsiya otnosheniy (istoriko-pravovoy aspekt) [Population and its Representatives 
in the Government: Evolution of Relations (Historical and Legal Aspects)]. Vestnik Permskogo universiteta. Yuridicheskie nauki - Perm University Herald. Juridical Sciences. 2016. Issue 4(34). Pp. 366-378. (In Russ.). DOI: 10.17072/1995-4190-2016-34-366-378.

34. Stavka refinansirovaniya $T_{s} B R F$ na segodnya $i$ $z a$ vse gody (s 1992 po 2017) [The Refinancing Rate of the Central Bank of the Russian Federation Today and for All the Years (from 1992 to 2017)]. Available at: https://bankirsha.com/all-rates-of-refunding-of-the-central-bank-with-1992.html. (In Russ.).

35. Stiglitz J. Globalizatsiya: trevozhnye tendentsii [Globalization and Its Discontents]. Moscow, 2003. 304 p. (In Russ.).

36. SShA i konstitutsionnyy perevorot v Rossii 1993 goda [The USA and the Constitutional Coup in Russia in 1993]. Available at: http://alumni. mgimo.ru/page/adaptive/id331360/blog/305745 $1 /$ ?ssoRedirect $=$ true $\quad$ (accessed 10.06 .2017 ) (In Russ.).

37. Syrykh V. M. Rossiyskie pravovedy na pereput'ye: materialisticheskiy ratsionalizm ili sub"ektivnyy idealizm [Russian Jurists at the Crossroads: Materialistic Rationalism or Subjective Idealism?]. Zhurnal rossiyskogo pravaJournal of Russian Law. 2016. Issue 1. Pp. 7589. (In Russ.).

38. Uspekhi i provaly "Rosnano": v chem obvinyali rukovodstvo kompanii [Successes and Failures of "Rusnano": What was the Management of the Company Accused of?]. Available at: http://www.aif.ru/dontknows/actual/1321673 (accessed 25.07.2017). (In Russ.).

39. Frolov A. S. Liberal'no-rynochnyy ekstremizm. $O$ strategii razvitiya vneshnego obrazovaniya $v$ sovremennoy Rossii [Liberal Market Extremism. Strategy of the Development of External Education in Modern Russia]. Svobodnaya mysl' XXI - Free Thought XXI. 2016. Issue 3. Pp. 71-84. (In Russ.).

40. Khabrieva T. Ya., Luk'yanova V.Yu. Pravo $i$ ekonomicheskaya deyatelnost' [Law and Economic Activity]. Obshchestvennye nauki i sovremennost' - Social Sciences and Contemporary World. 2016. Issue 3. Pp. 5-21. (In Russ.).

41. Kholodkov V. M. Strukturnye reformy v Rossii $i$ kitayskiy opyt [Structural Reforms in Russia and the Chinese Experience]. Problemy natsional'noy strategii - National Strategy Issues. 2016. Issue 5 (38). Pp. 161-190. (In Russ.).

42. Chernobel' G. T. Ideologicheskaya konstantnost' prava [Ideological Constancy of Law]. Zhurnal rossiyskogo prava - Journal of Russian Law. 2016. Issue 2. Pp. 5-15. (In Russ.).
43. Engels F. Pismo Y. Blokhu. 21-22 sent. 1890 g. [A Letter to J. Bloch. September 21-22, 1890]. Marx K., Engels F. Sochineniya [Works]. Moscow, 1965. Vol. 37. Pp. 394-395. (In Russ.).

44. Engels F. Pismo K. Shmidtu. 27 okt. $1890 \mathrm{~g}$. [A Letter to Conrad Schmidt. October 27, 1890]. Marx K., Engels F. Sochineniya [Works]. Moscow, 1965. Vol. 37. Pp. 416-421. (In Russ.).

45. Baum R. Burring Mao: Chinese Politics in the Age of Deng Xiaoping. Princeton, 1994. 528 p. (In Eng.).

46. Beck M. Plenarrede zur Ukraine. Available at: http://marieluisebeck.de/artikel/13-03-2014/ plenarrede-zur-ukraine (accessed 31.07.2014) (In Germ.).

47. Evans R. Deng Xiaoping and the Making of Modern China. 1995. 384 p. (In Eng.)

48. Frye T., Ora J., Szakonyi D. Hitting Them with Carrots: Voter Intimidation and Vote Buying in Russia. Date Written: 17 December 2016. Available at: https://ssrn.com/abstract $=2705075$ (accessed 05.05.2017) (In Eng.).

49. GDP at market prices (current US\$). World Bank website. Available at: http://data.worldbank.org/indicator/NY.GDP.MKTP.CD/countries/1W?display $=$ default (accessed 11.05.2016) (In Eng.).

50. Goldman M. Sowing the Seeds of Democracy in China: Political Reform in the Deng Xiaoping Era. Cambridge, 1994. IX. 426 p. (In Eng.).

51. Hale H.E. 25 Years After the USSR: What's Gone Wrong? Journal of Democracy. 2016. Vol. 27. Issue 3. Pp. 24-35. (In Eng.).

52. High-technology exports. World Bank website. Available at: http://data.worldbank.org/indicator/TX.VAL.TECH.CD/countries/1W?display= default (accessed 10.05.2016) (In Eng.).

53. Hinz L. Russland-Beauftragten Erler im Interview: "Putin hat einen nationalen Rauschzustand erzeugt". FOCUS-Online. 28.02.2015. Available at: http://www.focus.de/politik/ausland/ukraine-krise/interview-mit-dem-russlandbeauftragten-erler-von-den-knienaufstehen-putin-hat-einen-nationalen-rauschzustand-erzeugt_id_4508784.html (accessed 17.04.2016) (In Germ.).

54. Kettle M. Russia is a hostile power, but this is not a new cold war. The Guardian. 2014. 24 April. Available at: http://www.theguardian. com/commentisfree/2014/apr/24/ russia-hostilecold-war-ukraine-putin-new-strategy (accessed 21.05.2016) (In Eng.).

55. Kissinger $H$. World order: Reflections on the Character of Nations and the Course of History. Washington, 2014. 432 p. Available at: https:// www.amazon.com/World-Order-Reflections- 
Character-Nations-ebook/dp/B00MQA5OO4 (accessed 30.12.2014) (In Eng.).

56. Onyszkiewisz J. Putin's Russia: an empire that wants to be a civilization. European Leadership Network. 2015. 2 March. Available at: http:// www.europeanleadershipnetwork.org/putins-russia-an-empire-that-wants-to-be-a-civilization_24 80.html (accessed 10.05.2016) (In Eng.).

57. Major Foreign Holders of Treasury securities. Available at: ticdata.tzeasuzu.gov/Publish $/ \mathrm{mth}$. txt. (accessed 26.06.2017) (In Eng.).

58. Rahr A. Deutschlands Ostpolitik hat die Balance verloren. Spiegel-Online - Politik. 2013. 18 March. Available at: http://www.spiegel.de/ politik/ausland/alexander-rahr-deutschlands-ostpolitik-hat-die-balance-verloren-a-889270.html (accessed 21.07.2014). (In Germ.).

59. Schockenhoff: Russland ist auf Gasexporte angewiesen. Deutschlandfunk. 16.06.2014. Available at: http://www.deutschlandfunk.de/gasstreit-ukraine-russland-schockenhoffrusslandist-auf.694.de.html?dram:article_id=289230 (accessed 16.05.2016). (In Germ.).

60. Science and Engineering Indicators 2016. The National Science Foundation, NSF. Available at: http://www.nsf.gov/statistics/2016/nsb20161 /\#/digest (accessed 24.05.2016). (In Eng.).

61. The World Factbook. CIA website. Available at: https://www.cia.gov/library/publications/resources/the-world-factbook/geos/ja.html (accessed 04.05.2016). (In Eng.).

\section{References in Russian}

1. Авакьян C. Конституция и Парламент: размышления по поводу юбилея // Российская Федерация сегодня. 2008. № 23. С. 23, 16-19.

2. Балибар Э., Валлерстайн И. Раса, нация, класс. Двусмысленные идентичности. М.: Изд-во «Логос», 2004. 288 с.

3. Баранеи В., Гамов А. Тайны расстрела «Белого дома» // Комсомольская правда. 2008. 3 окт. URL: https://www.perm.kp.ru/daily/24 174/385092/ (дата обращения: 12.12.2008).

4. Галутвина О. К. Партии и власть // Свободная мысль ХХІ. 2004. № 9. С. 77-86.

5. Гессен В. М. Основы конституционного права. Пг.: Изд. юрид. кн. склада «Право», 1918. $445 \mathrm{c}$.

6. Добрынина Е. Как по-русски будет счастье // Российская газета. 2017. 7 июля.

7. Егоров И. Сыграл на инструментах // Российская газета. 2017. 3 марта.

8. Емельяненко Вл. Собственная гордость // Российская газета. 2017. 29 марта.

9. Законный брак // Российская газета. 2009. 17 апр.
10. Зеленко Б. И. О правовой демократии в РФ, власти и социуме // Вопросы философии. 2013. № 10. URL: http://vphil.ru/index.php? $\mathrm{id}=834 \&$ option=com_content\&task=view (дата обращения: 30.12.2013).

11. Зорькин В. Праворазрушители // Российская газета. 2017. 27 апр.

12. Зыкова T. По большому счету // Российская газета. 2017. 25 янв.

13. Иванов В.Н. Приватизация: итоги и перспективы // СоцИс. 2007. № 6. С. 48-60.

14. Ивантер B. Вот новый разворот // Российская газета. 2016. 30 нояб.

15. Кастельс М. Информационная эпоха: экономика, общество и культура. М.: ГУ ВШЭ, $2000.608 \mathrm{c}$.

16. Кастельс М. Новые индивидуальные массмедиа // Свободная мысль XXI. 2006. № 5. C. 62-67.

17. Крауч К. Постдемократия. М.: Изд. дом Гос. ун-та - ВШЭ, 2010. 192 с.

18. Кудров В. М. Выход из кризиса и инновационная модель экономики // Общественные науки и современность. 2013. № 4. С. 5-15.

19. Кунина А.Н., Рубанцова Т. А. Проблема преодоления правового нигилизма // Юридические науки: проблемы и перспективы: материалы IV Междунар. науч. конф. (г. Казань, май 2016 г.). Казань, 2016. С. 1617. URL: https://moluch.ru/conf/law/archive/ 181/10095/ (дата обращения: 22.07.2016).

20. Лавренов С. Я. Отчуждение как политикоправовое явление // Вестник Академии права и управления. 2013. № 30. С. 26-33.

21. Лапаева В. В. Постсоветская теория права: философские основания и их юридикодогматическая конкретизация // Проблемы постсоветской теории и философии права: сб. ст. М.: Юрлитинформ, 2016. С. 146-179.

22. Лапаева В. В. Российская философия права в контексте западной философско-правовой традиции // Вопросы философии. 2010. № 5. URL: http://vphil.ru/index.php?id=136\&option =com_content\&task=view (дата обращения: 01.09.2010).

23. Лапаева B. B. Типы правопонимания: правовая теория и практика. М.: Рос. акад. правосудия, 2012. С. 315-322.

24. Леонов $H$. «Перестройка»: четверть века спустя // Свободная мысль. 2016. № 3. С. 17-34.

25. Маркс $K$. К критике политической экономии. Предисловие // Маркс К., Энгельс Ф. Соч. М.: Гос. изд-во полит. лит., 1959. Т. 13. C. 5-9.

26. Маркс K. Капитал. Критика политической экономии // Маркс К., Энгельс Ф. Соч. М.: Гос. изд-во полит. лит., 1960. Т. 23. 907 с. 
27. Маркс K. Критика Готской программы // Маркс К., Энгельс Ф. Соч. М.: Политиздат, 1961. T. 19. C. 9-32.

28. Маркс К., Энгельс Ф. Немецкая идеология // Соч. М.: Партиздат, 1934. Т. 3. С. 7-544.

29. Мусаелян Л. А. Исторический процесс и глобализация. Пермь, 2016. 128 с.

30. Мусаелян Л. А. О цветных революциях, глобальном кризисе демократии и политической системе современной России // Вестник Пермского университета. Юридические науки. 2012. Вып. 3(17). С. 33-44.

31. Примаков E. Стимул к переменам // Российская газета. 2010. 8 апр.

32. Провал медведевской реформы МВД. Кто за это ответит? // Красноярское время. URL: http://krasvremya.ru/proval-medvedevskoj-reformy-mvd-kto-za-eto-otvetit/ (дата обращения: 12.03.2017).

33. Реутов В. П. Население и его представители во власти: эволюция отношений (историко-правовой аспект) // Вестник Пермского университета. Юридические науки. 2016. Вып. 4(34). C. 366-378. DOI: 10.17072/19954190-2016-34-366-378.

34. Ставка рефинансирования ЦБ РФ на сегодня и за все годы (с 1992 по 2017). URL: https://bankirsha.com/all-rates-of-refunding-ofthe-central-bank-with-1992.html (дата обращения: 12.03.2017).

35. Стиглии Дж. Глобализация: тревожные тенденции. М.: Нац. обществ.-науч. фонд, 2003. $304 \mathrm{c}$.

36. США и конституционный переворот в России 1993 года. URL: http://alumni.mgimo.ru/ page/adaptive/id331360/blog/3057451/?ssoRe direct=true (дата обращения: 10.06.2017).

37. Сырых B. М. Российские правоведы на перепутье: материалистический рационализм или субъективный идеализм // Журнал российского права. 2016. № 1. С. 75-89.

38. Успехи и провалы «Роснано»: в чем обвиняли руководство компании. URL: http://www. aif.ru/dontknows/actual/1321673 (дата обращения: 25.07.2017).

39. Фролов А. С. Либерально-рыночный экстремизм. О стратегии развития внешнего образования в современной России // Свободная мысль. 2016. № 3. С. 71-84.

40. Хабриева Т. Я., Лукъянова В. Ю. Право и экономическая деятельность // Общественные науки и современность. 2016. № 3. C. 5-21.

41. Холодков В. М. Структурные реформы в России и китайский опыт // Проблемы национальной стратегии. 2016. № 5(38). C. 161-190.
42. Чернобель Г. Т. Идеологическая константность права // Журнал российского права. 2016. № 2. C. 5-15.

43. Энгельс $\Phi$. Писмо Й. Блоху. 21-22 сент. 1890 г. // Маркс К., Энгельс Ф. Соч. М.: Политиздат, 1965. Т. 37. С. 394-395.

44. Энгельс Ф Письмо К. Шмидту. 27 окт. 1890 г. // Маркс К., Энгельс Ф. Соч. М.: Политиздат, 1965. Т. 37. С. 416-421.

45. Baum R. Burring Mao: Chinese Politics in the Age of Deng Xiaoping. Princeton: Princeton University Press, 1994. 528 p.

46. Beck M. Plenarrede zur Ukraine. URL: http:// marieluisebeck.de/artikel/13-03-2014/plenarrede-zur-ukraine (дата обращения: 31.07.2014).

47. Evans R. Deng Xiaoping and the Making of Modern China. Penguin Books, 1995. 384 p.

48. Frye T, Ora J, Szakonyi D. Hitting Them with Carrots: Voter Intimidation and Vote Buying in Russia. Date Written: December 17. 2016. // URL: https://ssrn.com/abstract=2705075 (дата обращения: 05.05.2017).

49. GDP at market prices (current US\$). Worldbank website. URL: http://data.worldbank. org/indicator/NY.GDP.MKTP.CD/countries/1W ?display=default (дата обращения: 11.05.2016).

50. Goldman M. Sowing the Seeds of Democracy in China: Political Reform in the Deng Xiaoping Era. Cambridge: Harvard University Press, 1994. IX+426 p.

51. Hale H. E. 25 Years After the USSR: What's Gone Wrong? // Journal of Democracy. July 2016, Vol. 27, № 3. Pp. 24-35.

52. High-technology exports. Worldbank website. URL: http://data.worldbank.org/indicator/TX. VAL.TECH.CD/countries/1W?display=default (дата обращения: 10.05.2016).

53. Hinz L. Russland-Beauftragten Erler im Interview: "Putin hat einen nationalen Rauschzustand erzeugt" // FOCUS-Online. 28.02.2015. URL: http://www.focus.de/politik/ausland/ukraine-krise/interview-mit-dem-russland-beauftragten-erler-von-den-knienaufstehen-putin-hateinen-nationalen-rauschzustand-erzeugt_id_450 8784.html (дата обращения: 17.04.2016).

54. Kettle M. Russia is a hostile power, but this is not a new cold war // The Guerdian. 24 April 2014. URL: http://www.theguardian.com/commentisfree/2014/apr/24/russia-hostile-cold-warukraine-putin-new-strategy (дата обращения: 21.05.2016).

55. Kissinger $H$. World order: Reflections on the Character of Nations and the Course of Histori. Washington: Penguin Press HC, 2014. 432 p. URL: https://www.amazon.com/World-OrderReflections-Character-Nations-ebook/dp/B00M QA5OO4 (дата обращения: 30.12.2014). 
56. Major Foreieyn Holders of Treasuru securities. URL: ticdata.tzeasuzu.gov/Publish/mth.txt (дата обращения: 26.06.2017).

57. Onyszkiewisz J. Putin's Russia: an empire that wants to be a civilization // European Leadership Network. 2 March 2015. URL: http://www.europeanleadershipnetwork.org/putins-russia-an-empire-that-wants-to-be-a-civilization_2480.html (дата обращения: 10.05.2016).

58. Rahr A. Deutschlands Ostpolitik hat die Balance verloren // Spiegel-Online - Politik. 18.03.2013. URL: http://www.spiegel.de/politik/ausland/alexander-rahr-deutschlands-ostpolitik-hat-die-balance-verloren-a-889270.html (дата обращения: 21.07.2014).
59. Schockenhoff: Russland ist auf Gasexporte angewiesen // Deutschlandfunk. 16.06.2014. URL: http://www.deutschlandfunk.de/gasstreitukraine-russland-schockenhoffrussland-ist-auf. 694.de.html?dram:article_id=289230 (дата обращения: 16.05.2016).

60. Science and Engineering Indicators $2016 / /$ The National Science Foundation, NSF. URL: http://www.nsf.gov/statistics/2016/nsb20161/\#/ digest (дата обращения: 24.05.2016).

61. The World Factbook // CIA website. // URL: https://www.cia.gov/library/publications/resour ces/the-world-factbook/geos/ja.html (дата обращения: 04.05.2016). 